\title{
シルク・ロードの地理学的諸問題 (1)
}

\author{
保 柳 睦 美* \\ Geographical Riddles of the Old Silk Road(1)
}

By

Mutsumi HoYANAGi**

\begin{abstract}
There are many problems still unsolved in the geographical studies of the Silk Road, which in ancient times connected Asia and Europe culturally and materially.

1. Who was the proposer of the name of the Silk Road? Richthofen introduced the term of "Seidenstrassen" in his "China, I", as well as in the article discussing this route in 1877 , and there is no doubt about that Richthofen has popularized the name. The name itself, however, was probably used for the first time in the account of the Greek geographer Marinus of Tyre in about 100 A. D., who had drawn his information from Maës Titianus, a Macedonian silk-merchant who sent agents to China during the 1st century of our era.

2. The study of the Silk Road by Richthofen was very instructive and suggestive, in spite of the time in which it was made when detailed maps of Inner Asia were not prepared and the European translation of the Chinese old annals and records were scarce. Although Richthofen's study had some faults, he had a good command of many important Chinese old annals and predicted many of the geographical problems which have been hottly discussed since the early part of the 20 th century, based on discoveries made by the scientific expeditions of Sven Hedin and Aurel Stein. (Fig. 1)

3. The study by Herrmann was scientifically equipped because of the time in which many European translation of the Chinese old annals and records were prepared and some of the results of the scientific expeditions of Inner Asia were published. The weak point of Herrmann's conclusion, however, lies in that he was too confident in the figures of distance of different oasis states from Ch'ang-an and Wu-lei, given by the Former Han Annals.

In ancient times in China, li was not used as one of the official units of distance and was only used as a rough estimate. It was more probable that commonly a day's travel equalled $100 \mathrm{li}$. As a consequence, the assumption of the position of many states and the old road based on the calculation of detailed figures of li of the Former Han Annals was in some parts far from the facts of the past. (Fig. 2)

4. The most reliable routes were obtained by the work of Stein, though it is not free from criticism. In the study of the Silk Road, however, it is desirable to begin with the close investigation of topography and other natural conditions along the road.
\end{abstract}

* 東京都立大学理学部地理学教室

地学雑溗 730 号, 1962 年

** Dept. of Geography, Faculty of Science, Tokyo Metropolitan University 
Fig. 3 shows the topography and the distribution of settlements and oases scattered along the margin of the Tarim basin, compiled from the maps prepared by the Army Map Service, Corps of Engineers, U.S. Army $(1: 1,000,000)$ and the maps of Chinese Turkestan and Kansu surveyed by Aurel Stein $(1: 500,000)$. A glance at the map shows that the distribution of large oases are confined to the foot of Tien-shan to the north and to the western half of the foot of Kun-lun to the south. The existence of large oases has close relations with the altitude of mountains and the extent of perpetual snow-field. Rivers nourished by large snow-fields flow down the mountains and have built large oases, such as Aku-su, Kucha to the north and Kashgar, Yarkand and Khotan to the west and to the south. The lands are flat and streamlets branch out, showing the character of delta lands rather than alluvial fans. The present highways run connecting those delta-oases and in ancient times the natural conditions were probably not so different from today.

5. Worth noticing, however, is that there scattered many small oases at the apex of the gigantic talus slopes of piedmont gravel, particularly to the southern margin of the basin, attaining in parts a relative height of $1,500 \mathrm{~m}$ and more and utterly barren. The path which connects these small talus-apex oases is winding but easy to get water, and even in ancient times it was frequently used as the by-road, particularly between Charchan and Khotan. (Fig. 4)

The main Silk Road between the two oases above described ran through the desert land, but the discoveries of many sand-buried sites by Stein, such as Endere, Niya and Dandan-oilik gave rise to a controversy about the route of the old highway. These sites were in the territory of ancient states of the Han dynasty, and Herrmann and some other historical geographers prefered to follow the ancient route running far off in the sandy desert. The assumption, however, is geographically unnatural, because it neglects the row of small delta-oases such as Niya, Keriya and Chira, which even in ancient times probably played an important part in the traffic and trade.

6. The most difficult part in the assumption of the old road is the eastern part of the basin, where oases are rare. The Tunhuang oasis is the last one from the "corridor" leading from north-western China into the Tarim basin. Along the foot of Pei-shan, particularly of Qruq-tagh (Dry mountains) to the north and of Altin-tagh to the south, there is no geographically natural route leading to the west, and the interpretation of the Chinese old annals and records brought about various old routes. But the discovery of one of the ruined sites of Loulan by Hedin in 1900 and abundant archaeological evidence studied by Stein brought to light the ancient route which skirted the northern part of the great saltencrusted sea bed and through Loulan reached the oasis of Korla.

The Former Han Annals, however, tell us that the Northern Road started from Turfan, and what had it to do with the old route through Loulan? Close exmination of the figures of li of Turfan from Ch'ang-an given by the Former Han Annals revealed that it was calculated from Tunhuang by way of Loulan and Korla, and it was proved that the old route through Loulan was an important highway, constituting actually a part of the Northern Road in the Former Han dynasty.

The route which skirted the southern shore of the great salt-encrusted bed was the 
main Southern Road, but it was and is very difficult route owing to the lack of water, and the by-road which ran from Tunhuang through some longitudinal valleys of Altin-tagh to Miran must have been frequently used.

7. The routes and their names changed according to periods. In the Former Han dynasty there were two highways, the Northern and the Southern Road. In the later part of the dynasty a new road was opened from Tunhuang directly to Turfan and in the Later Han dynasty it was substituted by the new road through the oasis of Hami. Therefore slight changes occurred in the names of the routes. In the Later Han dynasty, the Southern Road was the same with the former period, while the road which ran through Loulan and through the oases along the southern foot of Tien-shan to Kashgar was called the Central Road and the newly opened road to Turfan by way of Hami was called the Northern Road. Loulan was abandoned in the 4 th century, but the Annals of T'ang dynasty tell that the road through it was closed in the later part of the Sui dynasty. While in the Sui dynasty the new road which ran through the northern edge of Tien-shan was opened and was called the Northern Road. Therefore the Central Road, from Turfan to Kashgar, in this dynasty corresponded with the Northern Road in the Former Han dynasty. (Fig. 5)

Why then occurred such changes of routes? A greater part have been interpreted by the social and political changes along the routes in the history of the "Western Region". But some of them have remained unclarified. Why was the highway through Loulan closed? Why were Loulan, Miran, Endere, Niya, Dandan-oilik and others abandoned? These are problems beyond historical interpretation owing to the lack of historical records.

Geographically, however, more important problems are by what means did people live in those waterless sites in ancient times and why have these sites been buried in sand? We have been confronted by the most difficult geographical riddles. First of all, it should be ascertained whether or not the apparent shrinkage of rivers was the passing phenomenon caused by the arid period which covered over North China, Mongolia and probaly over Inner Asia in the beginning of the 20 th century, when many scientific explorations were made. Then changes of the natural environment during historical period should be reinvestigated, particularly the advance and retreat of ice and glaciers in the mountains. The change of wind action is also to be taken into consideration. At the same time we should notice that arguments about changes of the natural conditions during historical period in Inner Asia have been complicated and confused by considering too much the various natural and social accidents together, which probably had no relation with each other.

8. What economical profit was brought to ancient China by the silk trade? The historical study of Europe tells us that there was a serious adverse balance in Rome's oriental foreign trade which was made up by bullion or specie payments, and that Romans failed to balance with exports their great purchases of silk. Strange to say, however, we cannot prove that Roman specie payments reached China in a large amount, and some historical geographers say that they were more probably absorbed by middlemen. But another point which should be noticed is that some of the Chinese old annals and records tell us that the oases-towns were in full flourish and crowded with various shops and houses, which means a lot of money was spent in those transit towns. 
Up to what time had the function of the routes continued which deserved the name of the Silk Road? Romans succeeded to smuggle silk-moth eggs into the empire in the middle of the 6th century and sericulture was first developed in Syria and then it was carried to Sicily and Spain. With the introduction of sericulture into the Roman empire the commerce in raw silk began to dwindle and shortly after ceased altogether. But according to the sources of China, the Annals of the T'ang dynasty for example, the silk trade was still prosperous along the road even in the 7th century. Meanwhile came the dark years in the history of the "Western Region" following the end of Chinese control in T'ang dynasty and we cannot ascertain exactly the end of the silk trade. Probably the decline of T'ang rule in the Tarim basin synchronized with the end of the Silk Road, which was in the early part of the 8 th century.

\section{緒 言（その名の起り）}

シルク・ロード (絹の道) の名は最近の日本の社会では広く行き渡つていて, 中学校の歴史や地理の教 料書にも出てきている。そしてこれは古代に, 中国の特産物であつた絹が, 遠くヨーロッパ, ことにロー マ国へ運ばれたルートを指しているようである。そ机ではもつと具体的にいつて，どんなルートを通つて 絹が運搬されたのであろうか。

人々の中には, 漢の武帝のときに西域への道が開かれ, ここを通つて絹の貿易がはじまつたように考え ているものがある。しかしこれは誤りであつて，中国産の絹は，もつと早くからギリシア，ローマへと どいていたのである。ギリシア人やローマ人は，中国人や中国のことを Serts とか Serica とよんだとい われているが—この語源についてはいろいろな説があるが，この中で絲，si，ssu の発音がギリシア語風 の ser となつてヨーロッパへ伝わつたことがもとであるとの解䣋が最も穏当なものであろう一ーヨーロ ッパの学者の研究1によると, バクトリア国王エウチデムス (Euthydemus) が 220 B.C. ごろ, Seres ま で遠征したとのことがあつて，これが記録に出てくる Seres の最初であるという。ただしこの場合の Seres は中国人ではなく, シベリアの民族を指し，絹の中継貿易に従事していたものにすぎない。したが つて Seres, Serica のよび方は，要するに絹を生産する人や国の意味であつて，まだ中国人や中国のこ とが、ヨーロッパヘ知られていない時代から使われていたものである2。

こうして中国の特産物であつた絹は, 早くから多くの中継者の手を経てヨーロッパまで達していたので あつたが,こういう古い中継ルートや直接の貿易ルートも含めて, 古代に中国の絹が送られたルートとし て, 東洋史学界では次の 3 種のものが区別されている3゙。

(a) ステップ・ルート モンゴリア, ジュンガリア, カザフスタンなどのステップ地帯を通り, 遊牧 民によつて継送されていたルート。

(b) オアシス・ルート＼cjkstart乾燥アジアに散在するオアシスを結ぶルートで，いわゆる西域を通つた重要 な陸路。

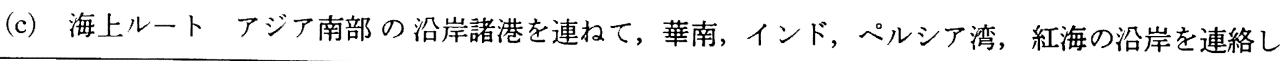

1) Tarn, W. W.: The Greeks in Bactria and India. Cambridge, 1951.

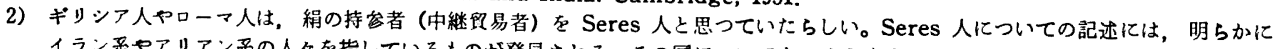
イラン系ャアリアン系の人々を指しているものが発見される。その国についても，加なりあとまでよくかかつていなかつた。たと えばその首府を Sera あるいは Sera Metropolis とょんでいたが, 首府が前漠時代の脣安から後谟の時代に洛隄に移ると, ア レクサンドリアの天文・地理学者プトレマイオス (Ptolemaeus)は、これを Sinae Metropolis とよんたのて、これによつ

3)

Its developmentern cultural contacts.

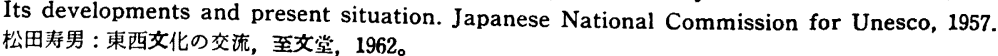


たもの。

しかしシルク・ロードとは，いかにも巧みにつけられた名である。こういら名が自然に発生するはずが なく,だれかが命名したものに違いない。そこでその命名者の意向を尊重して, これを取扱らことが必要 となる。

シルク・ロードの命名者はだれか。これは意外にも，はつきりさせることがむずかしい。しかし少なく ともこの名を普及させた人は, 当時ベルリン大学地理学教授であつたリヒトホーフェンであることは確実 である。すなわちその大著 China, I. で Seidenstrassen のよび方を使つているし，これを表題にした論 文もある”。そして，かれ以前にはこの名を使つた人がどうも見当たらない。それだからといってリヒト ホーフェンが命名者であるとは断定できない。こうしてシルク・ロードの研究は, その第 1 歩から, やつ かいな問題に当面してしまうのである5)。

ところでリヒトホーフェンが指しているルートは，漢の首都長安から西域を通つてパミールを越え， Oxus (アム川), Jaxartes（シル川）の流域に達した陸路である。このルートは前記の分類の（b）のおもな 部分に当たるものであるが,これは漢と西域ならびにそれ以西の国々との間に, 直接の貿易がはじめられた ルートとして重要な意味をもつものであるし，東西文化交流の点からは，最も重要な役割を果たしたもの である。したがつて以下，シルク・ロードとしてはこのルートを取上げ，いかに多くの疑問の究明が，今 後の地理学研究に委礼れているかを明らかにしたいと思う。

\section{I. リヒトホーフェンのシルク・ロート}

\section{1. その道すじと意義}

第 1 図は, リヒトホーフェンによつて描かれたシルグ・ロードの道すじである。当時の事情として，こ の地帯の地図自身に不正確な点が多いことはやむを得ないとしても，ここに記された道すじには，意外な ことがいくつか見出される。たとえばそのある部分は，タクラマカン砂漠を横断している。しかしこれ も，当時のかれとしては，よく考えてのことなのである。

リヒトホーフェンはこの地帯の古代の民族や交通に非常な関心をもち，マリノスやプトレマイオスの記 述や地図はもちろん，中国の古記録である漢書や史記なども参考にして，古代の貿易路について諭じてい る。ところでこの図に関連して起る種々な疑問についてはあとで触れることとして，かれのシルク・ロー ドの研究には，2つの大きな意義が認められるのである。

その 1 は, 19 世紀末から 20 世紀はじめにかけての, 列国の西域学術探検ブームが起る以前に, 中央ア ジア, ことに西域の歴史地理的意義の重大性を指摘していることである。これは非常な卓見といわなけれ

4) Richthofen, F. von: China. I., Berlin, 1877. Capt. 10, Entwicklung des Verkehrs zw. China und den Völkern im Süden und Westen von Central-Asien.

Richthofen, F. von: Ueber die centralasiatischen Seidenstrassen bis zum 2. Jahrhundert n. Chr. Verhandl. der Gesell. f. Erdk. Berlin, 96 122, 1877.

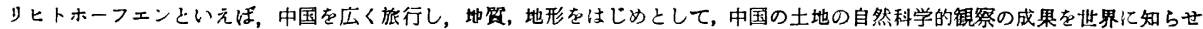
てくれた学者として日本では有名であるが，中国の歴史地理についても，すぐれた研究を行つているのである。えの著㫪 China， I. でもその約 $60 \%$ 严を歴史地理的研究に謷やしているほどである。

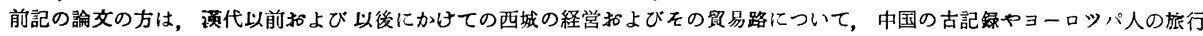
記などを利用して，その道すじを論じたものである。

このはか海上交通に䦔しては. Ueber den Seeverkehr nach und von China im Altertum und Mittelalter. Ver-

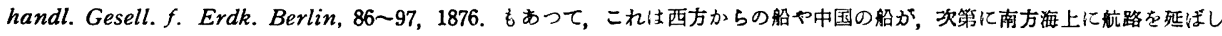
ていつた魏央地理的経過を明らかにしたものである。

5）あるいは Marinus か Ptolemaeus の記述のなかで,ことにマリノスの記述中にこの名が使つてあるかも知れない。マリノスはフ エニキアの港市 Tyre (Tyrus) の学者で，えの記述は，中国の势力が西城に回後した後演のころ，マケド二アの商人 Maës Titianus が, 絹留易のために旅行したとさの報告にもとずいて, 100 A.D. ころに絹の国への道のことを澘いたものである。プト レマイオスはアレクサンドリアの天文学者,地理学者で, 150 A.D. ころ, その著毒“地理”の中で,マリノスの記述にもとずき, さ

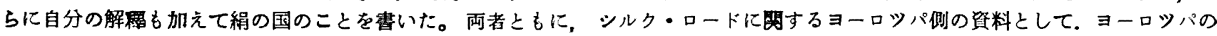
学界では重要視されてきたものである。リヒトホーフェンが, “マリノスの絹の道”という衣現をしているところから祭すると, マリノスの記述中にこの名が使つてある可能性が考えられる。 
第1図りヒトホーフェンのシルク・ロード

(The routes of the Silk Road, by F. von Richthofen, 1876.)

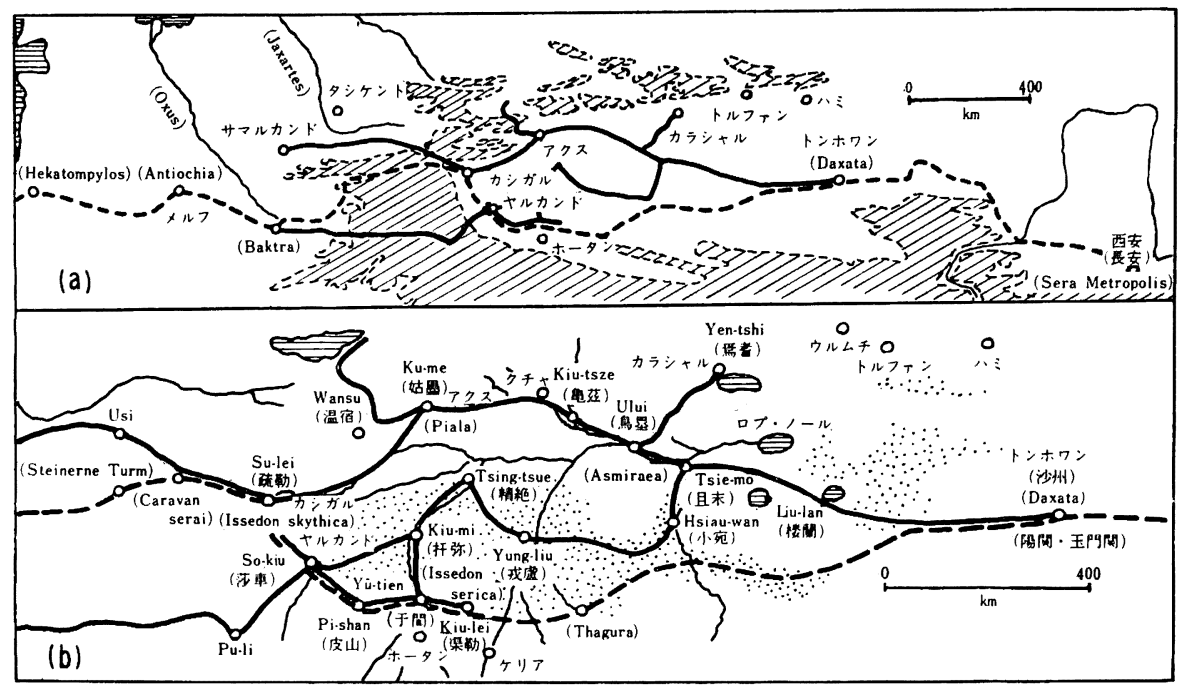

実線は中国の古記録から，破線はプトレマイオスの記述から推定された道すじ，カナ は現在名，（）は旧中国名またはプトレマイオスの記述中の名

ばならない。

その 2 は, 歴史時代におけるターリム盈地内の自然環境の変化を, すでに予想していることである。現 在のタクラマカン砂漠が横断できない自然環境にあることは, 地理学者であるリヒトホーフェンにはわか つていたはずである。それにもかかわらず第1図のようなルートを描いたのは，単に記録によればこうな ると推定したこと以外に，この地域の当時の自然には，現在と違つていた部分があつたと考えたからであ るらしい。すなわちその論文のなかで, 砂に埋れて滅亡しているオアシスの町のあることを述べているの である。これは大唐西域記や漢西域図考の記述（注，10，参照）あたりから示唆をらけたものかも知れな いが, ともかくリヒトホーフェンの記述の中には, そののち地理学, 歴史学, 考古学などの上に大問題と して浮び上つた多くのことが，すでに指摘してあることは，特筆に值することである。

\section{2. 当時の研究事情}

漢の武帝のとき, 西方の大月氏へ派遣された張謇の報告によつて, 漢の国土を取り囲んでいる蛮族居住 地帯の向う側には, フェルガナ(大宛), ソグディアナ(康居), カスピ海沿岸(奄蔡), バクトリア（大夏） などの地方（国々）があり，さらに遠方にはインド(身毒)，パルチア(安息)，バビロニア(條支)，エジプ ト(黎軒) などのような文化の高い国々があることがわかつた。そこでこれらの国々に漢の勢力を延ばすと 同時に，貿易によつて利益を得ようと考えて西方との間に交通を開き（当時この道は孔道をよばれた）,こ こを通つて中国特産の絹が大量にローマまでも運ばれるようになつたことはよく知られている。しかしこ の説明にもかなり直線的なところがあるが，ここでは，これに触れない。ただ，これによつて道路がはじ めて作られ，交通や貿易がはじまつたわけではないことには注意しなければならない。たとえばホータ ン付近に産する「芘崙の玉」は，もつと前から西域へ通ずる道を通つて中継貿易によつて中国へ運ばれて いたし，絹もここを通つて西方へ継送されていたのである。この道にシルク・ロードの名がつけられたの は，ここを通つて漠と西方との間の直接貿易が開かれたという点で一紀元を画すようになつたからであろ う。そしてそれは，106 B.C. に漢から絹をつんだ隊商が西方へ出発したときにはじまるものである。 
ところでこの道がどのように通つていたかを調べるには，むずかしい多くの問題が横たわる。第 1 に， かなり正確な地図が利用できなければならない。ところがこの地域については，現在の最良の地図でも， 未探検と記した空白の部分が方々に残されているありさまである。ましてリヒトホーフェンのころに は, ヘディーン (Sven Hedin, 1894 97, 1899 1902, 1927 35) やスタイン (Aurel Stein, 1900 01, 1906 08, 1913 15) その他の学者による学術探検が行われる以前のことであつたから，古い地図や記録 から，自分で地図を編修しなければならなかつたのである。

さらに大きな難関は，古い地名の考証である。シルク・ロード沿道の地帯では，歷史時代以前から種々 な民族の侵入や移動がはげしく行われたために，雑多な民族の居住舞台上なつている。だから地名や地域 名も，民族によつてよび方が違つていたし，次第に統一されたあとでも，たとえばサンスクリット系，イ ラン系, トルニ采, チベット系, 蒙古系などの言葉のものが混在しているのである。中国の漢書や史記に は，このへんの地名はすべて 漢字で書かれてあるが，これらは当時の現地発音のあるものに漢字をあては めたもの，その意味を漢字に訳したもの，漢の勢力下になつてから新たなよび方を作つたものなどがあつ て，現在のどこに当るものかを確めることが非常にむずかしく，古い地名の解釈いかんによつても，ずい ぶん違つた地図ができることになる。

第 3 に,リヒトホーフェンの時代には，ヨーロッパの学者で中国の古代史や歴史地理を研究している人 はまだ少なかつた。ことに中国の古記録については，ヨーロッパではその紹介や部分訳程度のものが出て いるにすぎなかつた。だから古記録の利用や解釈にも大きな困難があつたはずである。こういう状況のも とで研究されたものであるのに，その記述からは，引用されている欧文の文献以上に，多くの古記録が利 用されていることが察せられるのは不思議なことである。

\section{3. その根拠と疑問点}

以上のことを前置きとして，再びリヒトホーフェンの図を見直すと，これから興味ある事実や種々な疑 問を発見する。たとえば第 1 図 (b) では，ロプ・ノール（蒲昌海）の位置は恐らく 1863 年の大清一統興 地図によつたものであろうが，そんなに見当が外れていない。ところが 1877 年にプルチェワルスキーの カラ・コシュンの発見によつて，果然ロプ・ノール問題が学界をにぎわすようになつたものである6 ${ }^{6}$ 。

ところで最も問題なのは, ターリム盈地を通るシルク・ロードの道すじである。これは主として漢書の 記述によつたという。漢書の西域伝を開くと，

「西域以孝武時始通，本三十六国，其後稍分至五十余，皆在匈奴之西，烏孫之南”」

「西域諸国, 大率土著, 有域郭田畜, 與洶奴烏棌異俗, 故皆役属匈奴 $\left.{ }^{8}\right\rfloor$ というような有名な句が出てくるが, 問題のシルク・ロードについては,

「自玉門 - 陽関出西域, 有両道, 従垹善傍南山北, 波河西行, 至莎車, 為南道, 西踰苾嶺, 則出大月氏, 安息, 自車師前王廷, 隋北山, 波河西行, 至疏勒, 為北道, 北道西踰葱嶺, 則出大宛・康居・奄蔡焉”」

6）プルチェワルスキーは，カラ・コシュンを本当のロプ・ノールと考え，過去の中国の記绿や地図は謨つているものとした。この報

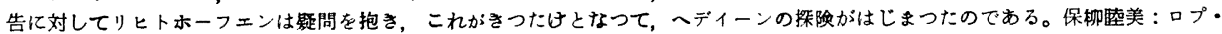
ノールの変還 (北支・蒙古の地理), 古今曐院, 1943. Hedin, S. : The Wandering Lake. New York, 1940. (岩村, 矢崎 訳, さまよえる湖, 纸摩整房, 1943).

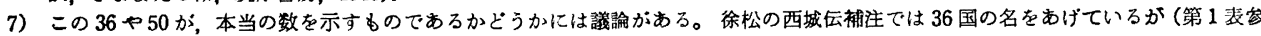
照), どれたけの根拠があるものかかからない。

8）前者括よびこの句によつて，当時の国々の位置や性格をうかがうことがでさる。これらの多くは天山の南に位し，多数のオアシス

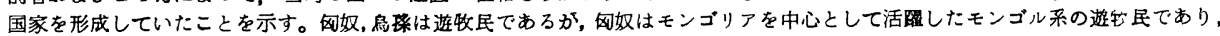

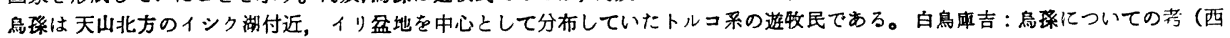
域史研究, 上), 岩波霎店, 1941。

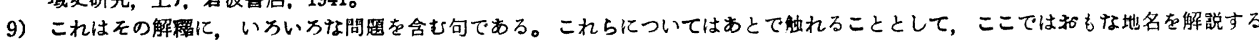

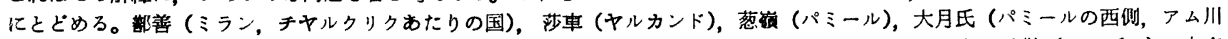
上流地方の国)，安息 (パハチア国，イランからメソポタミアにわたつた国)，車師前王国 (トルファン)，疏勒（カシガル）、大宛 (シル川上流，フェルガナ盈地を中心とした国），康居（シル川流域を中心とした遊牧民の国），都蔡（アラル海からカスピ海方面に わたつた遊牧民の国)。 
という, きわめて簡潔な説明が見出されるだけである。これではこまかいルートが全くわからない。そこ で他の手がかりからこれを求めなければならないが，幸いに漢書には，各国の長安からの里数や，西域都 護府への方向と里数も書いてある。この解釈には非常にむずかしい問題が含まれるのであるが, リヒトホ 一フェンはこの里数も考虑に入れるとともに他の手がかりも参考にして, 南道に沿ら国々である且末, 小 宛, 我盧, 精絶, 扞弥などの位置を図のように推定し, これらを連ねて砂漠を横断するような南道を描い たのである101。

このルートには今日からみると確かに不合理なところが多いし，この添北道やパミール方面のルート についても疑問がある。しかしこの図が描かれた当時のことを考えずに, 欠点ばかりを指摘しても意味が ないことである。要するにリヒトホーフェンのシルク・ロードは, 当時としては相当な根拠と, かれ一流 の解釈のもとに, 最初に地図に描か九たものとして, その価值を認めてよいものである。

\section{II. ヘルマンのシルク・ローF}

\section{1. その根拠}

シルク・ロードの研究が進むにしたがつて，この道は単に絹貿易だけでなく，東西の文化交流に対して 予想外に大きな役割を果してきたものであることがわかつたので，20世紀に入つてからは，ヨーロッパで も東洋でも，文化史の観点からの研究が主体を占めるようになつた。したがつてリヒトホーフェンの研究 をうけつぐものはしばらく現われなかつたが, そのうちにヴュルッブルグ大学地理学教授へルマンの研究 が出た ${ }^{11}$ 。これはわが国の歴史学界でも，かなり高く評価されていたものである。

ヘルマンの研究はのときには, ヨーロッパの学者による中国の古い記録の研究もかなり進む一方 ${ }^{12}, 、$ 、 ディーン, スタイン, グリュンウェデル, ル・コックなどの学術探検の成果も，その一部が公表されてか

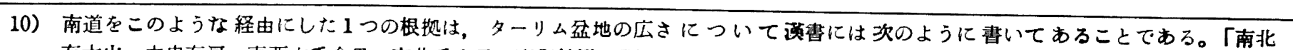

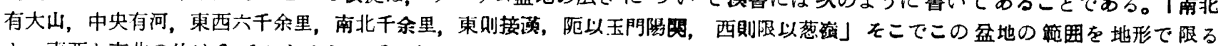

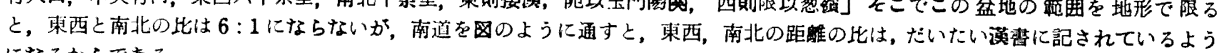
になるからである。

このほか, 㕕奖の大唐西域記の記逃や，清の李光廷の著である汿西域四获のことも知つていたものと想像される。前者には南道

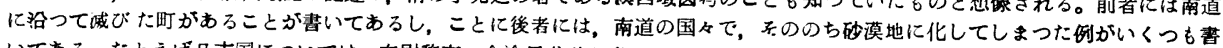

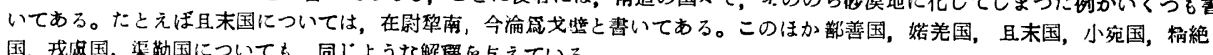
国, 我庭国, 渠勒国についても、同じょうな解濢を与えている。

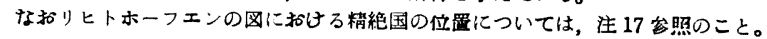

11) Herrmann, A.: Die alten Seidenstrassen zwischen China und Syrien. Beitraege zur alten Geographie

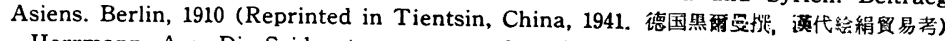

Herrmann, A.: Die Seidenstrassen vom alten China nach dem Roemischen Reich. Mitt. Geogr. Gesell. Wien, 58. 472 500, 1915.

このほかにもまた䛨んでいないが, 次の諭交もある。Die Verkehrswege zw. China, Indien und Rom um etwa 100 nach Chr. Leipzig, 1922. Das geographisches Bild Chinas im Altertum Sinica. Forke-Festschrift Sonderausgabe, 1937.

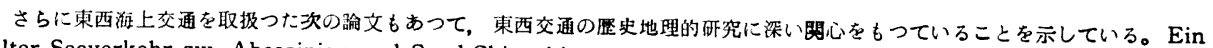
alter Seeverkehr zw. Abessinien und Sued-China bis zum Beginn unserer Zeitrechnung. Zeit. Gesell. Erd. Berlin. 553 561, 1913. Die alten Verkehrswege $z$ w. Indien und Sued-China nach Ptolemaeus. Zeit. Gesell. Erd. Berlin, 771 787, 1913.

12）へルマン自身が果してどの程度に㴖文がこなせるのかわからないが，をの引用文中には，西域に閣する古い記睩について，现在で もョーロッハの学者䦓で重要祝され利用されている次のような臤文訳や研究成果がすでに含まれている。

Wylie, A.: "Notes on the Western Regions", translated from the Former Han Annals. Jour. of the An.

Hirth, F.: China and the Roman Orient. Shanghai, Leipzig u. Muenchen, 1885.

Hirth, F.: Syrisch-chinesische Beziehungen im Anfang unserer Zeitrechnung. (in R. Oberhummer u. H. Zimmerer: Durch Sycien und Kleinasien, Berlin, 1899).

Chavannes, E.: Documents sur les Turcs occidentaux. St. Petersburg, Acad. Imp. des Sciences, 1903.

Chavannes, E.: Les pays d'Occident d'après !e Wei lio. T'oung-pao, 1905.

Chavannes, E.: Les pays d'Occident d'après le Heou Han Chou. T'oung-pao, 1907.

Chavannes, E.: Les Mémoires Historiques de Se-Ma T'sien. 5 Vols, Paris, 1895 1905. 
らであるから ${ }^{133}$ ，これらの資料もよく利用されている。またこの地域の地図も，すでにかなりよいものが 出てきていたし、へディーン，スタインの探検によるものも利用されている。このようにりヒトホーフェ ンの研究時代とちがつて, 資料がずつと豊富になつてからのことであるから, その研究も科学性が濃いも のである。

ヘルマンの論文を読むと，ヨーロッパの学者でありながら，中国古代の考証に非常な努力を払つている 点は驚くほどである。けれどもその研究態度は，基本的にはリヒトホーフェンの場合と同様である。すな わちシルク・ロードの研究に対して, 最も信頼できる記録は漢書であるとし, ヨーロッパ側の資料はそれ ほど重視していないことである。こうして漢書に現われている諸国の里数を基本とし，国々の位置とシル ク・ロードの道すじを明らかにしょうとした。このような態度をとつたのには, かれとしての理由があ る。

前に引用した漢書の句によっても，シルク・ロードの道すじはきわめて漠としたものである。ターリム 盈地の南縁と北縁のオアシスをそれぞれ東西に連ねるものが南・北道の幹線であり，これが西方ではパミ 一ルを越すことはわかるが, もつと具体的に,これらの道すじが現在のどういう地点を，どのように連ねて いたものかがわからない。ところが前にも触れたよらに, 漢書には, 西域諸国の長安からの里数, 西域都護 府への方向と里数その他が書いてある (第 1 表)。これらのうちで里数は, 漢が西域を統治する上に重要な 意味をもつていたはずだから，信頼ができるものと考えた。すなわちこの数字こそ問題を解く最も重要な 手がかりであると考えたわけである。そこで漢時代の 1 里は, 現在のどれくらいの距離に相当するかを推 定するために, 過去の里数と現在の距離とをいくつか比較して平均した結果, 1 里 $=390 \mathrm{~m}$ （約 $400 \mathrm{~m}$ ) で あることを知つた。これを基準として古い地名を現在のそれと照合させてみると，プトレマイオスの記述 や地図は，あまりにもこの基準から外れていること，およびマリノスの記述の方がむしろ参考になること がわかつた。それはそのはずで, プトレマイオスは決して当時のすぐれた地理学者ではなく，むしろ天文 学者であつたから、ヨーロッパとアジアとの距離もマリノスの記述にしたがわずに，地表の陸地の大きさ に対する自説から割り出したものに違いないからである。こうしてへルマンは現在の地図の上で，まず学 術探検によつて明らかにされた諸地点をおさえ，さらに古い記録を参考にしながら漢書に書かれた里数を 案配して，古代の他名および道路の考証を行つたのである(第 2 図)。

ヘルマンのシルク・ロードはリヒトホーフェンのそれと異なつていることは当然のこととしても，この 地域の現在の通路ともかなり違つている部分がある。まず, 玉門, 陽関を出てから道は 3 本にわかれる。 このうち北へ向うものは，八ミを経てトルファンへ通ずるものであるが，伊吾（八ミ）の地名が記録に出 てくるのは後漢になつてからである。前漢時代にはこのへんは匈奴の勢力下にあつたから，まだ道は開か れていなかつたものである。したがつてこの道は，あとで通じた新道と考えなければならない。また玉 門, 陽関を出てから南へ向つて山を越えるものもあるが, これは本道からわかれてッァイダム盈地を通 り, チベットへ入るものを示したものらしい。したがつてこの図における前漢時代の本道は, 口プ・ノー

13）当時はすでと次の報告㫪が利用できたことになる。

Hedin, S.: Die geographisch-wissenschaftlichen Ergebnisse meiner Reisen in Zentralasien (1893 96),

Peterm. Erg. H. 131, Gotha, 1900.

Hedin, S.: Scientific results of a journey in Central Asia 1899 1902, 8 Vols, Stockholm, 1904 07.

Stein, A. : Preliminary report of a journey of archaeological and topographical exploration in Chinese

Turkestan. London, 1901.

Stein, A.: Sand-buried ruins of Khotan. Personal narrative of a journey of archaeological and geographical exploration in Chinese Turkestan. London, 1904.

Stein, A.: Ancient Khotan. Detailed report of archaeological explorations in Chinese Turkestan. 2 Vols, Oxford, 1907.

Gruenwedel, A.: Bericht ueber archaeologische Arbeiten in Idikutschari u. Umgebung im Winter 1902 03. Abh. d. Kl. d. Kgl. Bayr. Acad. d. Wiss. XXIV, 1. Abt., Muenchen, 1906.

Le Coq: Bericht ueber Reisen u. Arbeiten in Chinesisch-Turkestan. Zs. f. Ethnologie 39, 1907.

Huntington, E.: The pulse of Asia. Boston, 1907. 
第 2 図 ヘルンのシルク・ロード

(The routes of the Silk Road, by A. Herrmann, 1910, 1915)

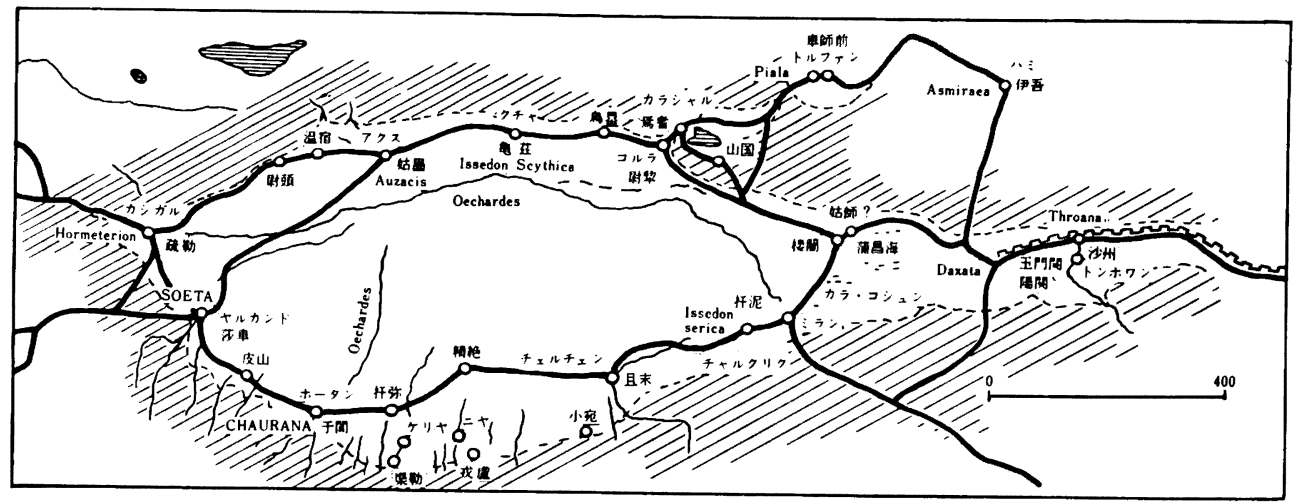

漢字は旧地名,カナは現在名, ローマ字はマリノスの記述にあるもの

ル（蒲昌海）の塩沢を迁回してローラン（楼蘭）に達し，これから1つはクルック・ダリアに沿つてコル ラ (尉犂)に向かうものと，他はローランから南西に向かつてクンルン山麓を縫らもの（南道）とにな る。

蒲昌海の北をまわつてローランに至るルートは，スタインの異常な努力によつて明らかにされたもので あるが，漢書によると北道はトルファンを通るように書いてあるから，漢時代には，玉門，陽関以後，ど ういうルートでトルファンに達したのであろうか。

トルファンから天山南麓へ出て, ここのオアシスを連ねながらカシガル (疏勒) に至る北道は, この図 では現在の道路上あまり変わつていない。ただアクス (姑墨) からカシガルに至る間は, カシガル川に沿 うもの（現在はこれが多く用いられている）よりも，もつと北の山麓に沿うものの方が多く用いられたら しいとい。

現在の道と著しくちがつている道すじが目立つのはむしろ 南道である。ことにチェルチェン（且末）か らホータン (干闐) に至る間は, 現在よりもずっと北側の砂漠地を通つている。こ机は精絶国と扞弥国の 位置を，図のような砂漠中に推定したことがおもな原因と思われるが，上にかく種々な問題を含む地帯で ある。

カシガルからパミールを越える道についてもいろいろ論ぜられているが, 結論として, 陽関からカシガ ルに至る各道の距離を次のように計算して, 中道（ローランを通つてコルラに達し，あとは天山南麓を縫 うもの。中道という名は魏略西戎伝に出てくる。注 31 参照) がいかに重要な近路であつたかを物語るも のとしている。
（1）中道（注, コルラで漢時代の北道に連絡）
$\{$ (2) 南道（注, ヤルカンド, カシガル間を含む)
(3) 北道（注，八ミ経由の新道を含む）
$1,700 \mathrm{~km}$ （旅程 7 週間）
$1,900 \mathrm{~km}$ (旅程 8 週間)
$2,100 \mathrm{~km}$ (旅程 9 週間)

\section{2. その弱点}

ヘルマンの研究はその着想もおもしろく，また種々な資料，ことにへディーン，スタインの探検の成果 をよく利用している。しかしその根本的態度は，漢書に示された各国の里数を最も重視するという，はつ きりした仮定のもとに成立つているものである。だからこの仮定がくずれると，すべてが動摇してくるこ とになる。

まず第 1 表をみると，漢書に記された里数の取扱いが，いかにむずかしいものであるかの見当がつく。 
第 1 表 漠書西域伀に記述してある西域諸国の名, 距離, 規模

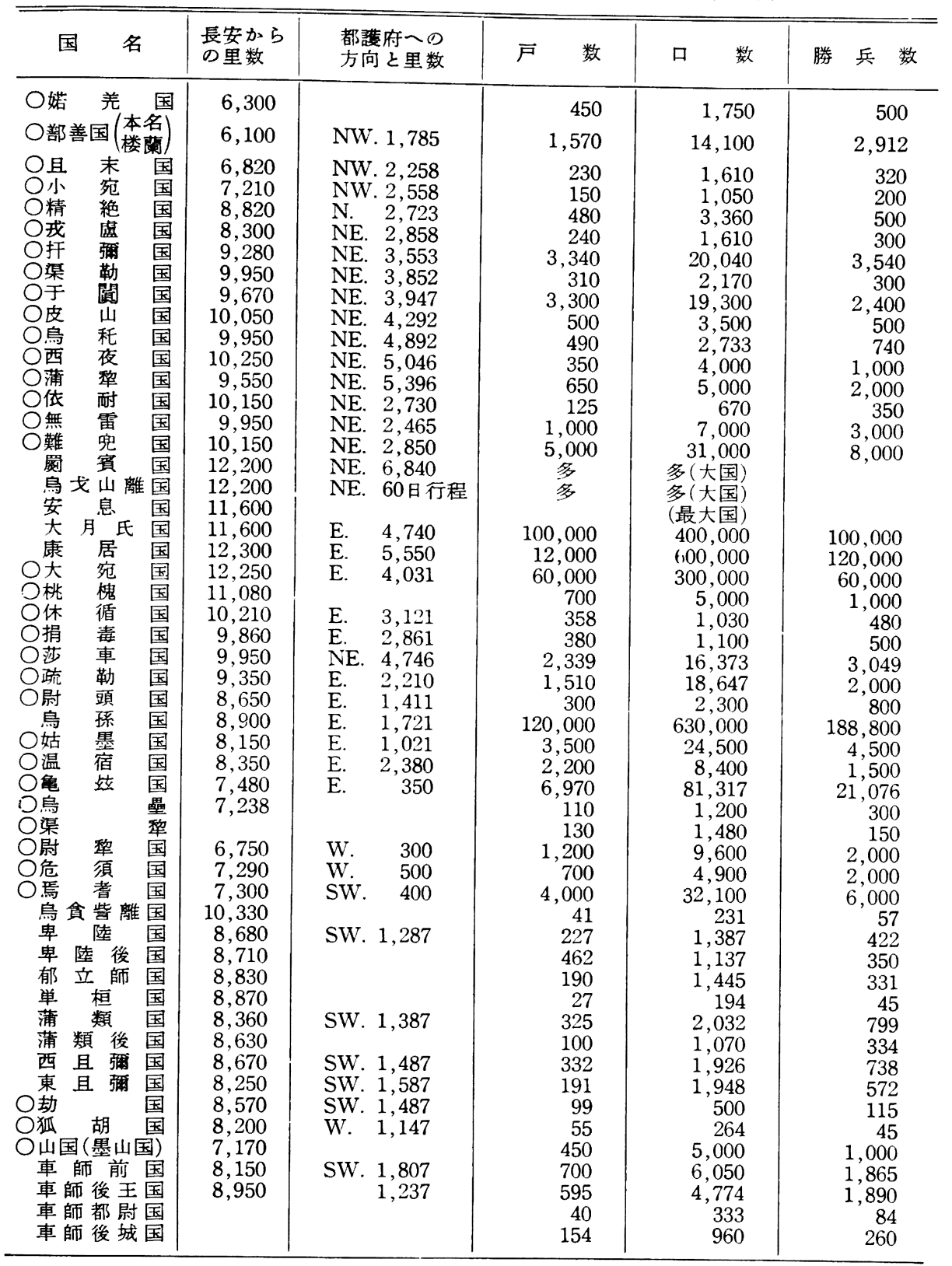

○印は清の徐松（1781～1848）の漢書西域伝補注に記されている36国，（とのほか子合国， 姑師国が加わつて計 36 国となる)。とれが哀帝，平帝のとろ，さらに分れて 55 国になつた と説明されている。 
これは直線距離でなく, 実際の道のりである。漢書にはこのほか, 隣国間の里数が記入されている場合も あるが，それにしてもこれだけの資料から各国の分布状態を推定することは，クイズを解くような難事業 である。しかもこの表によると, 長安里数と都護府里数とでは数字の性質がちがつていて, 後者は 1 ケタ まで出ている。このことは, 距離の出所が，両者で全く別であることを示す。またこのことは，漢書の重 大な性格を現わすものである。すなわち漢書は, 玄奜の大唐西域記のように, 自分で旅行し, 現地が見聞 したことを記述したものとちがつて，種々な資料から編修されたものであるということである。だからそ の記述の中には，単なるいい伝えもあろうし，時には資料の整理の混乱から来た誤りもあり得る ${ }^{14}$ 。

だから漢書の記述は全体としてすぐれたものであつても, この中の里数がどの程度をで信頼できるかが 問題である。まず長安里数から 4,500 里 (清の徐松の西域伝補注による長安, 陽関間の里数)を減ずると, 陽関（玉門関，陽関の区別は考えられていない）から各国までの距離になるが，こんなことでは解釈の米 口もつかめない。だから徐松のように, これらの数字の多くのものに疑問をもつ学者が出たのも, もつと もなことである。ことに都護府里数を眺めると，最後の 2 ケ夕の数字が類似しているものが多く，、かに も不自然な感を与えるし，その他にも不審な点が見出される ${ }^{15 !}$ 。

ヘルマンはヨーロッパの学者であるから, 中国の古記録にある数字に対してもヨーロッパ的に考えて, 中国的立場からこれを分析することができなかつたのであろう。実は漢代には一般に，1 日の旅程が 100 里と概算されていたと考える方が，す心゙ての資料について好都合なのである ${ }^{16)}$ 。だから都護府里数のよう に1ケタまで出ていても, 要するにある地点から何日行程ということであり, その基点から都護府への里 数に 100 の倍数を加えただけだから，最初に現われた 2 ケタの数字は, あとまで残ることになる。長安里 数もこまかい数字にこだわらずに，何日行程の程度に考える方がよい。

こうして漢書の里数を概略的なものにみても，長安里数と都護府里数とが, 容易に両立しない場合もし ばしばであつて，これをどう処理するかによつて，国の位置が違つてくる。へルマンもこの点では苦ん で，自説に都分がよいように片づけている場合が多い17)。したがつてへルマンの立場とはほとんど反対 に, 松田教授 ${ }^{18)}$ のように, 多くの史伝をよく調べてこれを批判することを基本とし, 里数には参考資料的 意味しか認めない立場も成り立つ。むしろアジアの歷史学者の研究態度としては，この方が納得がいくの である。

けれども，ここでは，漢時代における西域の国々の分布そのものを問題としているのではなくて，当時 のシルク・ロードがどう通つていたかを, まず明らかにしたいのである。この意味からは, へルマンの図 で最も疑問が多いのは, 敦煌, カシガル間の前半の部分であり, 次いでパミール越え, およびそれ以後の ルートである。しかし後者については私もまだよく調べていないので，以下ではおもにターリム盈地内の ルートについて論ずることにする。

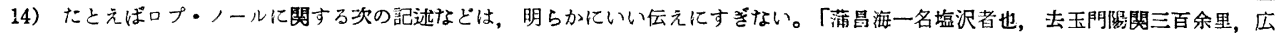

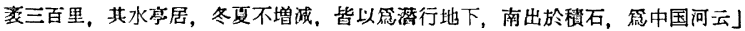

15）たとえば車師後王国（シニンガリアのジムサ付近）の方が車師前国（トルフアン付近）よりも都滥府に近い。車師前国の距雄は 1,087 里の摆りであろう。

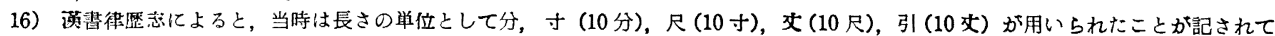
いるが, 里は正式の単位に含まれていない。里は步とともに早くから発生した名称であるが, 一般に地積の単位（步里法）に用い られていた。里が正式汇長さの単位に加光られたのは清代からであり(呂承洛：中国度量衡史，鄗務印柏馆，1937，1957)。したが

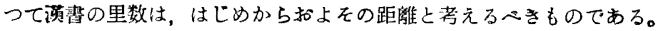

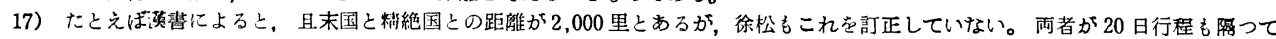
いたのでは，たの位置の推定がつかない。これでわかつたことは、リヒトホーフエンの南道では，精絶国の位路を，盛地中央よ

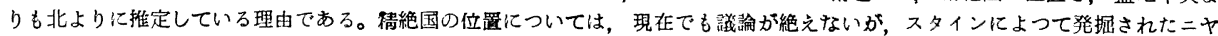
遇跡を，これ対比している人があつて，ヘルマンもえの1人である。これはクンルン山笓よりも，ずつと北部の砂漠中である。

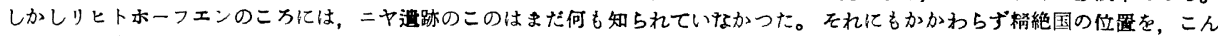

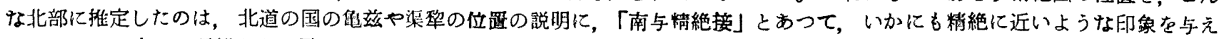
ることと, 且末との距碓 2,000 里に，何とかつじつまを合わせようとした結果と思われる。

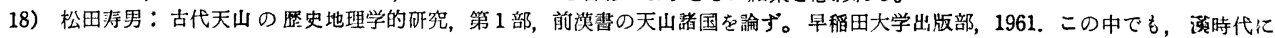
は，1日行程が 100 里と見糟られていたことが推論されている。 